\title{
Strengthening The National Resilience of Indonesia Through Socialization of National Insight
}

\author{
Mrs. Isabella \\ Department of Government Science \\ Faculty of Government Science and Culture \\ University of Indo Global Mandiri Palembang Indonesia \\ Email: isabella@uigm.ac.id
}

\begin{abstract}
In the community, nation and state, today is experiencing with the times. Indonesia as a country with a vast territory and a population has also changed significantly in many sectors. These changes will certainly bring influence on the dynamic state of this country with regard to ductility, and toughness needed to develop strength and ability to address all threats, challenges and interference both from within and outside. This condition is called national resilience. Therefore, we need a strategy that is appropriate for the current condition so that national resilience of Indonesia can be implemented, protected and maintained. The strategy is also important to produce strength and care for the interest of Indonesia. The number of cases of abuse against symbols of the state, the lack of knowledge of younger generation towards the concept of nationalism are two examples of this nation's problems. 0 ne of the efforts made by the House of Representatives in the MPR, DPR and DPRD in cultivating national security is through socialization of national insight. The socialization of national insight would make a positive contribution to the national resilience of Indonesia. The success of this socialization can be seen from the efforts that have been made so far.
\end{abstract}

Key words: national resilience, socialization of national

insight, students

\section{INTRODUCTION}

In the life of society, nation, and state, Indonesia experienced changes that follow the times. As one country with an area of 5,193,250 $\mathrm{km}^{2}$, and with a population of 260 million more. With the geographical condition of the archipelago there are 17,504 islands. This will certainly affect the dynamic conditions of the nation related to tenacity, and resilience to develop national strengths and capabilities in order to overcome all threats, challenges, disturbances, both from within and from outside known as national resilience.

National resilience is a condition as well as national development in achieving the goals and ideals of the nation. As a condition, national resilience is a dynamic state of the nation that contains the resilience and tenacity and ability of the nation to develop national power, to face of all kinds and forms of threats, challenges, obstacles, and disturbances both coming from within and outside, threatening and endangering integrity, identity and survival of the nation and state. Threats, challenges of national resilience are now beginning to emerge through various forms. Such as the negative impact of globalization and modernization.

A survey of the younger generation and related to national values by Kompas daily showed that the result of the spirit of unity was weakened $(56.8 \%)$ and prioritized group interests $(77 \%)$ compared to the interests of the nation $(21.2 \%)$ likes to be part of Indonesia (50.9\%). Furthermore, in relation to the revitalization of national insight, based on the result of BPS RI survey on the Survey of Country Life (SKB) conducted in 2011, with $43.4 \%$ of the trust and expectation of the community were so much for the teachers and lecturers to provide education and socialization values of Pancasila.

Various efforts have been made to equip the young generation, in this case high school students, to maintain the love of the homeland and nation, fostering a sense of nationalism, a sense of unity and unity of the nation. Among them are socialization of national values that have been done by senators through DPR RI, and DPD RI during recess. There is the need to further efforts in preserving the sense of nationalism, love of the homeland and the nation, so that what has been championed by the heroes of independence is maintained for the save of the Republic of Indonesia.

\section{LITERATURE REVIEW}

\section{A. The Basic National Resilience Law}

The basic of national resilience law consists of: a) Idiil Basis: Pancasila, related to the resilience of the state, Pancasila in particular the third precepts that oblige every citizen to have a sense of unity and unity both in the sense of ideology, economics, social culture, patriotism value, upholding the tradition of the struggle, and willingness to sacrifice in the resilience of the nation and the State. 
b) Constitutional Basis: Constitution of the Republic of Indonesia 1945 (UUD 1945). Article 27 paragraph 3 of the 1945 Constitution states that every citizen shall have the right and obligation to participate in the resilience of the State. Article 30 paragraph 1 of the 1945 Constitution stipulates that every citizen shall have the right to participate in the maintenance and security of the State.

c) Operational Basis: the operational basis of resilience business of the State, among others as follows: 1) Law Number 2 Year 2002 regarding the Police of the Republic of Indonesia; 2) Law Number 3 Year 2002 on State Resilience; 3) of Law Number 34 Year 2004 regarding Indonesian National Army.

National resilience is the dynamic condition of the Indonesian nation that encompasses all national life that is integrated and contains tenacity and resilience, which contains national strength to face all challenges of threats, obstacles and disturbances, both coming from within and from outside, and also to guarantee identity, integrity, and survival of the nation and state and the struggle to achieve national goals (Prayitno and Trubus, 2013).

Empirically, the statement can be described as follows: (1) The strength of the power that causes a person or something to survive, strongly suffers or can cope with the burden it carries; (2) The tenacity is a genuine effort to achieve the goal; (3) Identity is characteristic of a nation or State viewed as a whole. The State is seen as a community organization bounded by territory, with its population, history, government and national goals and with its international role; (4) Integrity, which is the whole unity in the national life of a nation both social and natural elements, both potential and functional; (5) A threat is an attempt to change or revise policies and efforts undertaken conceptually, criminally, and politically; (6) Challenge, that is effort that is evocative ability. This usually happens because of a coercive condition, causing a person or group to feel obliged to do something to face any challenge; (7) Obstacles are the business of oneself Disorders are efforts that come from outside, are and are intended to weaken and / or hinder not conceptually.

According to Prayitno (2003: 256) Conception of Indonesia's resilience is the conception of the development of national power through the arrangement and implementation of prosperity and security that are harmonious in all aspects of the life of the State as a whole and thoroughly integrated based on Pancasila, 1945 Constitution and Nusantara Insight. Conceptually there are three "faces" depicted in the national resilience scheme, namely: a) National Resilience as a reality or real; 2) National Resilience as a conception; c) NationalResilience as a method of thinking or approach method.
As outlined in the National Guidelines of State Policy (GBHN) of 1998 the definition of national resilience is defined as follows:

1) In order to keep the national development going forward which must always be toward the objectives to be achieved and to be effectively avoided from the obstacles, challenges, threats and disturbances arising from both inside and outside, the national development is carried out through a National Resilience approach that reflects integration between all aspects of national life as a whole and comprehensive.

2) National resilience is a dynamic condition that is the integrity of the condition of every aspect of life of the nation and the State. In essence, national resilience is the ability and resilience of a nation to be able to guarantee the survival to the glory of the nation and the State. The success of national development will increase national resilience. Furthermore, robust national resilience will promote national development.

3) National resilience includes ideological resilience, political resilience, economic resilience, socio-cultural resilience and security resilience.

\section{B.National Resilience Principles}

The principles of national resilience consist of:

a) Welfare and Security Principles, this principle needs a very basic and must be met for individuals, groups and communities. In the life of the nation and the state, these welfare and security elements are usually the benchmarks for the National Security's Resilience;

b) The principle of integrated comprehensiveness, meaning that national resilience encompasses all aspects of life. These aspects are related in a harmonious, harmonious and balanced form of unity and synthesis;

c) The principle of self-consciousness inward and outward. In this case introspective the aims to foster the nature and conditions of national life based on the value of values to the nation's independence. While introspection outward done in order to anticipate foreign strategic;

d) The principle of kinship. This principle contains living attitudes that are imbued with justice, togetherness, commonality, mutual cooperation, tolerance and responsibility in the life of society, nation and state. In daily life, this familial principle still recognizes the difference, but the values of harmony is preferred.

\section{Nature of National Resilience}

Some properties of National Resilience can be explained, as follows: 
a) Independent, it means believing in the ability and strength itself and not easily give up. This nature is a prerequisite to establish a cooperation based on the nature of independence;

b) Dynamic, meaning not fixed, up and down, depending on the situation and condition of the nation and the State and its strategic environment. This dynamic is always oriented toward the future and directed to better conditions;

c) Authority, meaning the continuous and sustained development of the National Security, remain in order to improve the strength and ability of the nation. The direction to be achieved for the Indonesia is to have self-esteem and be noticed by other nations in accordance with the quality attached to it;

d) Consultation and Cooperation, meaning mutual respect by relying on the moral strength and personality of the nation. Both relationships need to be implemented in a communicative way so that there is openness in seeing the condition of each;

\section{Position and Function of National Resilience Conception}

National resilience is based as a conceptual foundation, based on Pancasila as the ideal basis and the 1945 Constitution as the constitutional foundation in the national development paradigm. While the functions of national resilience are:

First, the conception of national resilience in its function as a basic national doctrine. This needs to be understood to ensure that the pattern of attitudes, patterns of behavior, patterns of action and work patterns are in place to integrate the nation's interregional, inter-sectoral and multidisciplinary steps; Second, the conception of national resilience in its function, as the basic pattern of national development. This function is the direction and guidance in the implementation of national development in all sectors and sectors of development in an integrated manner, which is done according to the program design;

Third, the conception of national resilience in its function as a method of fostering national life. The method is an integral method that encompasses all aspects of the life of the State known as eight aspects consisting of the natural aspect (geography, natural wealth and population, resilience and security).

\section{E. Socialization of National Insight}

According Soerjono Soekanto (2007) socialization is the process by which new member of the community learn the norms and values of the community in which becomes a member. Meanwhile, according to Robert M.Z. mace, socialization is the process of studying norms, values and roles and all other requirements necessary to enable effective participation in social life. Furthermore, according to Bruce J. Cohen, socialization is the process of human learning in the way of life in society to gain personality and build capacity so that it can function properly as individuals and as members of a group.

According to Bruce J. Cohen in Soerjono Soekanto (2007) socialization has several objectives, namely: (1) Socialization aims for each individual to get the provision of skills that later he will need to stay alive; (2) The purpose of the socialization is for each individual to communicate effectively, so that the ability to read, write, and speak can develop; (3) Socialization aims to control the function of organic functions through proper selftraining exercises; (4) Socialization aims so that each individual can familiarize himself with the values and beliefs that are central to the community; (5) Establish a behavioral system through experience that is influenced by his personal character, that is how he reacts to an experience toward the maturing process.

The Insight of nationality can be interpreted as a perspective or perspective that contains the ability of a person or group of people to understand the existence of identity as a nation in view of themselves and behave according to the nation's life philosophy in the internal and external environment (Suhadi and Sinaga, 2006). According to Muladi (2015) the understanding of Indonesian nationalism is the perspective of the Indonesian nation about themselves and their environment, prioritizing unity and regional unity in organizing the life of society, nation and state.

The nature of national insight can be interpreted the perspective of the whole person or group in prioritizing the interests of the state and nation. The basic value of national insight is manifested in six fundamental and fundamental dimensions, which consist of: (1) Appreciation of human dignity as the creature of God Almighty; (2) Love of the homeland and nation; (3) People's democracy or sovereignty; 4) The common denominator for a free, independent and united national life; (5) The society is just and prosperous; and (6) Social solidarity.

The meaning of national insight can be realized through the following matters: (1) The vision of nationality mandates to all nations to place unity and unity, and interests, and the safety of the nation above the interests of individuals or groups; (2) The vision of nationality does not give place to the cunning patriotism; (3) The national insight develops Indonesian unity in such a way that the principle of Bhineka Tunggal Ika is maintained; 4) Unified, sovereign, just and prosperous NKRI, determined to realize a developed and independent nation and inner and outer prosperity, parallel to other developed nations; 5) With the vision of nationality based on the Pancasila life view, the Indonesian nation has successfully paved the way in carrying out mission in this life. 


\section{DISCUSSION}

Broadly speaking, national resilience and national insight are two major concepts in an effort to counteract the negative effects and impacts of technological advancement, the environment, which is accompanied by changing perceptions and threats to the existence and sovereignty of the nation. Along with technological advances, information and communications that have impacted modern warfare in the form of Proxy War.

The spirit of nationalism and national insight which is the motivation to defend the Unitary State of the Republic of Indonesia requires the support of various parties and is the responsibility of all components of the nation. In order to avoid the various threats both from within and outside the country.

Various ways have been done to maintain national resilience today. Through the socialization of national insight as has been scheduled by the MPR RI through members of the House of Representatives and DPD RI. Various new concepts of socialization has become a special attention for the relevant institutions that continue to fight for the implementation of socialization of nationalism vision.

To socialize the national insight that is implemented by senator of DPD RI for example, every recess period, in one year there is agenda four times to carry out socialization of national insight. This socialization can be done in schools, campuses or community groups, which play an important role in receiving materials of national insight. In the socialization of national insight held by DPD RI usually invite experts, or speakers who are competent in their field. In addition to the socialization participants were given a package of books from the MPR RI in the form of Penitentiary of the 1945 Constitution of the Republic of Indonesia, the material of Pancasila as the State's Basic, NKRI as State Form, Unity in Diversity and MPR Tap. The display material made by the MPR RI secretariat team is made in such a way as to adapt to the present condition, using the projector media with power point slide. This is certainly different when the New Order period, the delivery of national insight material through Upgrading P4 (Guidance of Practice and Applying of Pancasila) through BP7 (Educational Development Board Implementation Guidance of Pancasila Practice).

Although the lecture method remains to be maintained, it is combined with technological progress. So this material can be accepted by the current generation. Hopefully through socialization the groups can resume, or inform the other members of the community about the importance of national insight in the effort to maintain national resilience.

Another thing the government attempted to socialize national insight, is by the issuance of Presidential Regulation No. 54 year 2017, concerning Work Unit of President of Ideology Development of Pancasila (UKP PIP) headed by Yudi Latif. One of the PIP UKP agenda programs related to strengthening national resilience is the return of students of Pancasila in cooperation with the Ministry of Education and Culture, as well as the Ministry of Higher Technology and
Education Research.

In its work program the UKP PIP is assigned to the practice of Pancasila in daily life in communities integrated with poverty and social welfare programs. In Article 3 of Perpres No. 54 of 2017 it is stated that the UKP's PIP duty assists the president to formulate the general policy direction of Pancasila ideology development and to coordinate, synchronize and control the development of ideology of Pancasila, thoroughly and sustainably. While article 5 states the organizational structure of UKP PIP consists of: Steering consists of elements: (1) State figures; (2) People of Religion and Society; (3) Retired Indonesian Armed Forces.

Other programs that the UKP PIP seeks to revitalize Pancasila's surge as the basis of the State, was the launch of the Pancasila Educational Empowerment Program in collaboration with the Ministry of Research and Technology of Higher Education, through an interactive and participatory approach, and watching together Pantja Sila's movie: Ideals and Reality.

As an effort to maintain national resilience, other institutions such as the National Resilience Institute (Lemhanas) RI As a State institution developing the concept of national resilience Indonesia has created a special body in charge of measuring the level of resilience Indonesia. This body is called the National resilience Measurement Laboratory.

In the implementation of efforts to strengthen national resilience, one of which socialization of national insight in schools, currently requires media in accordance with the present condition. For example, students in schools are now more interested in the visualization media, either through projectors or even documentary films of the nation's independence struggle, videos containing Pancasila and Citizenship education. If possible, students can be invited to participate in the making of their own films, according to their creative ideas related to strengthening national resilience.

For educational institutions such as schools and campuses can provide Pancasila and Citizenship materials through study visits to historical places or places that can provide educational content of the history of the struggle of the nation, such as museums, agencies or related agencies on duty maintaining national resilience such as Badan Kesatuan Bangsa dan Politik.

\section{CONCLUSION}

Indonesia's national resilience has been driven of being capable of counteracting various forms of threats so as not to lead to the destruction of the nation or the fragmented NKRI. The evidence of national resilience is at least evident from the way the Indonesian nation faced communist threats in 1965. In addition, Indonesia has passed the economic and political crisis of 1997-1998.

However national resilience will continue to face the dynamics of changing times. Various concepts of efforts 
to maintain national resilience through national insight have been conducted. Institutions that are deliberately formed by the government, schools, campuses and nongovernmental organizations, must continue to synergize, coordinate and conduct studies to maintain the NKRI. This effort is expected to anticipate the negative impact of globalization and modernization or proxy war. Given the threat of national resilience disorder will grow and vary in accordance with the progress of information technology is increasingly open.

As stated in Law No. 3 of 2002 on National Resilience that the Indonesian National Resilience is universal by determining the Indonesian National Army as the main component of resilience supported by reserve components and supporting components, especially in the face of military threats. Whereas in the face of nonmilitary threats, the resilience system places government institutions outside the resilience field as a major element in accordance with the form and nature of threats encountered with the support of other elements of the nation's power, including socialization of national insight held by various parties ranging from MPR RI, DPD RI, House of Representatives, to institutions that are competent in their field as the organizer of efforts to maintain national resilience.

\section{REFERENCES}

[1] Alie, Marzuki. (2016). Makalah Peran Alumni Nusantara dalam Mempertahankan Jati Diri Bangsa.5-6.

[2] Antara. (2017). Inilah Tugas dan Struktur UKP Pembinaan Ideologi Pancasila. Retrieved from http://kabar24.bisnis.com/read/20170607/15/660122/inilah-tugasdan-struktur-ukp-pembinaan-ideologi-pancasila

[3] Dirjend Pembelajaran dan Kemahasiswaan Kemenristekdikti. 2016. Pendidikan Pancasila untuk Perguruan Tinggi.

[4] Kaelan.( 2014). Pendidikan Pancasila. Yogyakarta: Paradigma.

[5] Lemhanas RI. 2012. Geostrategi Dan Ketahanan Nasional. Jakarta.

[6] Muladi. (2015). Wawasan Kebangsaan: Pengertian, Makna, Nilai. Retrieved from http://demokrasipancasilaindonesia.blogspot.co.id/2015/03/w awasan kebangsaan-pengertian-makna.html

[7] Nasional Kompas Retrieved from http://nasional.kompas.com/read/2017/05/24/17494671/sema ngat.kebangsaan.langkah.nyata.pemerintah.amat.dinanti.
[8] Peraturan Presiden Nomor 58 tahun 2015 about Kementrian Pertahanan.

[9] Prayitno and Trubus.(2003). Pendidikan KADEHAM Kebangsaan, Demokrasi, dan Hak Asasi Manusia, Jakarta: Universitas Trisakti.

[10] Rahman, Arief. (2017). Meningkatnya Nilai-Nilai Kebangsaan dapat Memperkokoh NKRI.

Retrieved from

https://pusatamalpancasila.wordpress.com/2012/08/07/menin gkatnya-nilai-nilai-wawasan-kebangsaan-dapatmemperkokoh-keutuhan-nkri-3/.

[11] Ranjabar, Jacobus. (2013). Sistem Sosial Budaya Indonesia. Bandung: Alfabeta.

[12] Republika. (2016). Retrieved fromhttp://www.republika.co.id/berita/koran/opinikoran/16/01/07/o0kjc51-wawasan-kebangsaan-kita.

[13] Sekjend MPR RI. (2014). Panduan Pemasyarakatan UUD NRI 1945, TAP MPR RI.

[14] Soekanto, Soerjono.(2007). Sosilogi Suatu Pengantar. Jakarta: Raja Grafindo Persada.

[15] Susanti, Astri. 2016. Makalah Dasar Hukum Ketahanan Nasional. STEKOM Welari, Kendal Jawa Tengah.

[16] Undang-Undang DasarNegara Republik Indonesia Year 1945

[17] Undang-Undang Negara Republik Indonesia Number 3Year 2002 about Pertahanan Negara. 